\title{
Soluble transforming growth factor $\beta$ type II receptor attenuates TGF-ß1 activity in human colorectal cancer LoVo cells
}

\author{
RUI ZHOU, BIN XIONG, HAIBIN SONG, SHIQUAN LIU and XINBO WANG
}

\author{
Department of Oncology, Zhongnan Hospital, Hubei Key Laboratory of Tumor Biological Behaviors, \\ Hubei Cancer Clinical Study Center, No. 169, Donghu Road, Wuchang District, Wuhan 430071, P.R. China
}

Received June 15, 2008; Accepted July 28, 2008

DOI: 10.3892/or_00000165

\begin{abstract}
Several lines of evidence support an important role of TGF- $\beta$ in the development of colorectal cancer, although the molecular consequences are largely unknown. Soluble transforming growth factor- $\beta$ receptor type II (sTßRII) is a target of transforming growth factors- $\beta$ (TGF- $\beta$ ) that plays an important role in regulation tumorigenesis, angiogenesis and metastasis of cancer. To elucidate whether overexpression of sTßRII could antagonize TGF- $\beta$ in colon cancer cells, we constructed a plasmid that contains a cDNA encoding human extracellular region of TßRII and transfected this construction into LoVo cells. Surprisingly, in the absence of TGF- 31 , the overexpression of sTßRII antagonized TGF- $\beta$-induced cell proliferation, invasion, motility and angiogenesis, and decreased expression of VEGF and MMP-9. Also, sTßRII inhibited TGF- $\beta$-induced apoptosis and improved the induction of antitumor immunity. Our data indicated that sTßRII attenuated the biological activities of TGF-B, suggesting that sTßRII may have a therapeutic benefit in colorectal cancer.
\end{abstract}

\section{Introduction}

Transforming growth factor- $\beta 1$ (TGF- $\beta 1$ ) is a multifunctional cytokine involved in the regulation of many biological processes and it has a major role in the initiation and progression of cancer $(1,2)$. In contrast to the tumor suppressive effects of the TGF- $\beta$ signaling pathways, is the striking finding that TGF- $\beta$ is widely overexpressed in many human cancers and this alteration in tumors is associated with poor prognosis, tumor vascularization and metastasis (2).

Colorectal cancer is one of the most common fatal malignancies worldwide. The reasons for this biological

Correspondence to: Professor Bin Xiong, Department of Oncology, Zhongnan Hospital, Wuhan University, Wuhan 430071, P.R. China

E-mail: binxiong88@yahoo.com

Key words: sTßRII, eukaryotic expression vector, proliferation, apoptosis, invasion, angiogenesis, immunity aggressiveness are unknown. However, TGF- $\beta$ plays an important role in the development of colorectal cancer $(3,4)$. In normal epithelial cells, TGF- $\beta$ has a predominant growthinhibitory effect and serves a tumor suppressor role. Thus, loss of growth-inhibitory responses to TGF- $\beta$ appears to be a common and important event that attends malignant transformation of epithelial cells and this occurs in colorectal cancer (5). The complex and multifunctional activities of TGF- $\beta$ endow it with tumor suppressor and tumor promoting activities, depending on the stage of carcinogenesis and the response of the tumor cell (6). Yan et al (7) found that TGF- $\beta 1$ stimulates proliferation though a Ras-dependent mechanism in colon carcinoma cells or some loss of sensitivity to TGF- $\beta(8,9)$. Thus, the role of TGF- $ß$ s in tumorigenesis is controversial. Studies have shown that at early stages of carcinogenesis the overexpression of TGF- 11 provides tumor-suppressive effects via growth inhibition, whereas at late stages TGF- $\beta 1$ induces angiogenesis and regulates the production of the extracellular matrix and proteolytic enzymes as well as the expression of adhesion molecules, making tumor cells more invasive and metastasis $(2,6)$. The mechanisms by which TGF-ßs confer a growth advantage to colorectal cancer cells in vivo have not been elucidated.

In our previous study, we found that TGF- $\$ 1$ levels in the serum of patients with colorectal cancer were significantly elevated compared to normal controls and overexpression of TGF- $\beta 1$ in colorectal cancer tissue were strongly associated with the invasiveness and metastasis of colorectal cancer $(10,11)$. We also showed that TGF- $\beta 1$ may be correlated indirectly with angiogenesis though an up-regulation of the expression of VEGF in colorectal cancer. Therefore, antagonizing the activities of TGF- $\beta$ may be informative for prevention and therapy of colon cancer. In the last decade, significant advances in cell biology have opened several ways to inhibit TGF- $\beta$ action (12-14). Attractive increasing attention is the use of a soluble TGF- $\beta$ receptor that appears selectively to inhibit metastatic disease in the MMTV-neu transgenic mouse model that were absent in the effects either on normal physiology or on tumorigenesis at the primary site (15). It can also inhibit established murine malignant mesothelioma tumor growth by augmenting host antitumor immunity (16). In the present study, we constructed a plasmid that contains a cDNA encoding human soluble TBRII receptor, and stably transfected this construction into 
the human colorectal cancer cell line, LoVo, to enhance the expression of soluble TßRII, further to determine if the overexpression of TßRII in tumor cells could prevent TGF- $\beta$ mediated tumorigenesis by directly binding to TGF- $\beta$ and attenuate its action on the cell proliferation and angiogenesis. We found that sTßRII inhibited cell proliferation, invasion and angiogenesis and decreased the expression of VEGF and MMP-9 via antagonizing TGF- $\beta$ activities in LoVo cells.

\section{Materials and methods}

Vector construction. The cDNA encoding the extracellular domain of human TßRII was amplified by PCR from the human colon tissues. PCR was performed using the sense primer, 5'-GCAAGCTTTCTGCCATGGGTCGGGGGCTG-3', and antisense primer, 5'-GCGGATCCCAAGTCAGGAT TGCTGGTGTTATATTC-3'. The sense primer introduced a HindIII restriction site and the antisense primer introduced a BamHI site (underlined). The cDNA for the extracellular domain (amino acids 1-159) of human TßRII was subcloned into the HindIII-BamHI sites of pcDNA3.1 (+).A pcDNA3.1 $(+)$ vector with neomycin resistance only was used as control. The sequence and orientation of the constructed pcDNA3.1 (+)/sTßRII was confirmed by dideoxy chain termination sequencing.

Cell culture and transfection. The human colorectal cancer cell line LoVo (American Type Culture Collection) was grown in RPMI-1640 (Life Technologies, Gibco). Cells were transfected with the mammalian expression vector pcDNA3.1 (+) or pCDNA3.1 $(+)$ /sTßRII. Transfections were performed according to the manufacturer's instructions (Lipofectamine, Gibco). Stably transfected cells were selected in the presence of G418 (600 g/ml) (Lingfei, Wuhan, P.R. China). For maintenance and culturing of transfectant clones, $400 \mathrm{~g} / \mathrm{ml}$ G418 were added to the medium. Single-cell clones were subsequently maintained in $400 \mathrm{~g} / \mathrm{ml} \mathrm{G} 418$, and positive clones for sTßRII expression were identified by screening via reverse transcription-polymerase chain reaction (RT-PCR).

RT-PCR analysis. Total RNA was isolated by TRIzol reagent (Invitrogen), as described by the manufacturer and semi-quantified spectrophotometrically. RT reaction was performed with $3 \mu \mathrm{g}$ RNA and random primer using a firststrand cDNA synthesis kit (MBI Fermentas). Transcripts of sTßRII, MMP-9, VEGF were amplified by PCR.

Western blot analysis. Forty-eight hours after transfection, the supernatant of cells in a $10 \mathrm{~cm}$ Petri dish was directly used for Western blot analysis. After boiling for $5 \mathrm{~min}, 10 \mu \mathrm{l}$ of each lysate was loaded onto a $10 \%$ SDS-polyacrylamide gel to resolve proteins. After electrophoresis, the proteins were transferred from the gels onto PVDF membranes. The membranes were blocked with $5 \%$ non-fat dry milk in Trisbuffered saline containing $0.1 \%$ Tween-20 (TBS-T), and then probed with antibodies against human TGF-ßRII (Boshide, Wuhan, P.R. China), 1:200 dilution. The membranes were washed with TBS-T and incubated with appropriate peroxidase-conjugated secondary antibodies for $1 \mathrm{~h}$ at room temperature. Finally, the proteins on the membranes were detected using an ECL chemiluminescence kit (Boshide).

Immunofluorescence. Forty-eight hours after transfection, the cells were washed in PBS, fixed in $4 \%$ paraformaldehyde in PBS at $4{ }^{\circ} \mathrm{C}$ for $30 \mathrm{~min}$ followed by incubation with $100 \%$ methanol at $-20^{\circ} \mathrm{C}$ for $10 \mathrm{~min}$. Thereafter, the cells were washed in PBS, incubated with 1:50 dilution antihuman TGFßRII antibody (Boshide) and applied for $30 \mathrm{~min}$. Incubation with affinity-purified FITC-labeled goat anti-rabbit IgG (Boshide) diluted 1:100 (v/v) lasted for $20 \mathrm{~min}$. Controls included substitution of the primary antibody by PBS.

Cell growth assays. The cell growth mediated by TGF- $\beta$ was determined with a 3-(4, 5-dimethylthiazol-2-yl)-2, 5-diphenyltetrazolium bromide (MTT) assay. To assess the growth inhibitory effects of TGF- 1 , LoVo, control vector-modified LoVo (LoVo/neo), and soluble TßRII-modified LoVo (LoVo/ sTßRII) cells were seeded at a density of 10,000 cells/well in 96-well plates in RPMI-1640 medium and incubated for $48 \mathrm{~h}$ before incubation for $48 \mathrm{~h}$ in serum-free medium in the absence or presence of TGF- $\beta 1\left(5 \mathrm{ng} \mathrm{ml}^{-1}\right)$. The assay was initiated by adding MTT solution at a final concentration of $100 \mu \mathrm{g}$ of MTT/well. Wells were then aspirated and $100 \mu \mathrm{l}$ of DMSO (Linfei, Wuhan, P.R. China) was added to each well, and the plate was shaken for $15 \mathrm{~min}$. Plates were read at $460 \mathrm{~nm}$ in a spectrophotometer.

Clone formation assay. LoVo, LoVo/neo and LoVo/sTßRII cells were plated at a density of 500/well on 6-well microtiter plates. After an overnight incubation to allow cell attachment, the medium was replaced by fresh medium containing $5 \mathrm{ng} \mathrm{ml}^{-1}$ TGF- $\beta 1$, with each cell type repeated in three wells. After being incubated for $48 \mathrm{~h}$, the medium was replaced by fresh medium containing $10 \%$ FBS. The cells were incubated for another 7 days, then washed thrice with PBS and fixed in methanol for $15 \mathrm{~min}$. The cells were stained with Giemsa stain. Then the number of clone-forming cells (>50 cells) was calculated under the microscope. The data were expressed as mean $\pm \mathrm{SD}$.

FITC-Annexin V and propidiumiodide (PI) staining. LoVo, LoVo/neo and LoVo/sTßRII cells were seeded incubation for $48 \mathrm{~h}$ in serum-free medium in the absence or presence of TGF-ß1 (5 $\mathrm{ng} \mathrm{ml}^{-1}$ ). The assay was performed using an annexin V-FITC apoptosis detection kit (CalbiochemPharMingen) according to the manufacturer's directions. Briefly, cells were washed in cold PBS and resuspended in assay buffer, and a $100 \mu 1$ aliquot was withdrawn for analysis. After addition of annexin V-FITC (which labels exposed phosphatidylserine) and the nuclear stain propidiumiodide (which stains permeable cells), the sample was incubated 15 min in the dark and then analyzed on a Becton Dickinson FACScan flow cytometer.

Tumor cell invasion assay. In vitro invasion assays were performed using BioCoat Matrigel Invasion Chambers (Becton-Dickinson Bioscience) according to the manufacturer's instructions. In brief, LoVo, LoVo/neo and LoVo/sTßRII cells that were preincubated for $48 \mathrm{~h}$ in MEM in the absence 
A

\section{12}

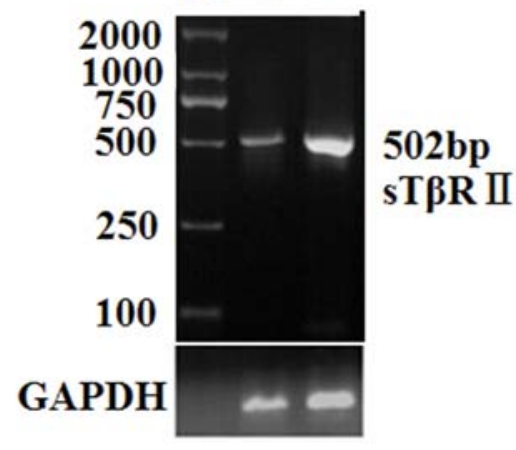

B

1

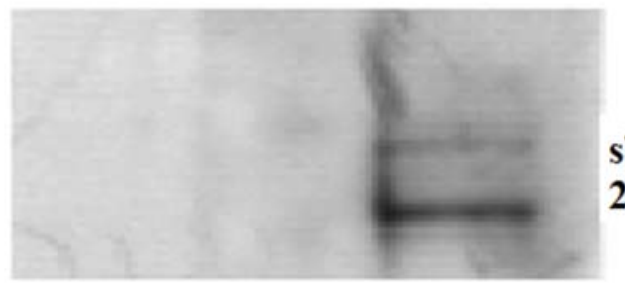

sT $\beta R$ II 25-35KD
C

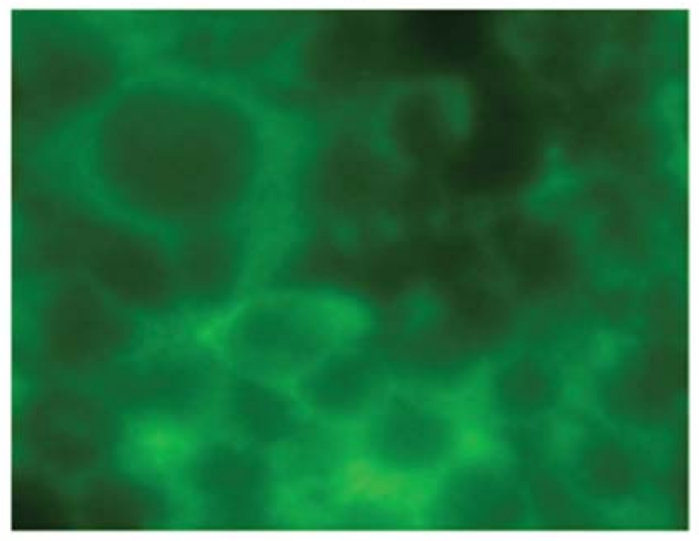

2

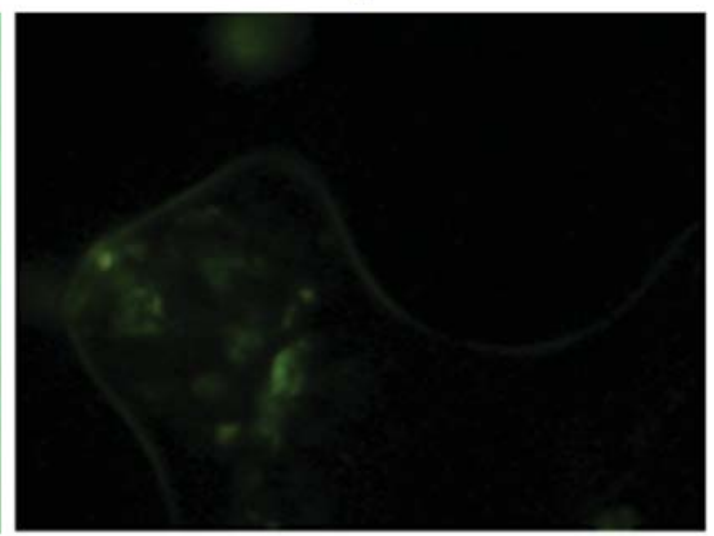

Figure 1. Identifying sTßRII expression in LoVo cells. (A) Identification of the LoVo cells by RT-PCR. M: Marker; 1, LoVo /neo cells. 2, LoVo/sTßRII cells. (B) Western blot analysis of culture supernatants from LoVo (lane 1), LoVo/neo (lane 2), and LoVo/sTßRII cells (lane 3). Heterogeneously glycosylated soluble TßRII of 25-35 kDa was detected in LoVo/sTßRII cells. (C) Immunofluorescent assay; 1, expression of sTßRII identified by immunofluorescent assay; 2, negative control.

of $5 \mathrm{ng} \mathrm{ml^{-1 }}$ TGF- $\beta 1$ were plated on the upper wells of Matrigel invasion chambers at a density of $0.5 \times 10^{5}$ cells/ $500 \mu \mathrm{l}$ in MEM. Medium containing 10\% FBS was applied to the lower chamber as a chemoattractant to induce invasion, according to the manufacturer's instructions. The cells were incubated for $48 \mathrm{~h}$ at $37^{\circ} \mathrm{C}$ and $5 \% \mathrm{CO}_{2}$, and the insert membranes were then prepared for microscopic samples. Membranes were fixed with $100 \%$ methanol and stained with the Wright-Giemsa (Lingfei). The number of cells on the lower surface of the membrane was counted by microscope (x250 objective) from 5 consecutive fields. Each assay was performed on duplicate filters, and the experiments were repeated twice. The harvested cells were counted, and the mean number of cells per chamber was calculated and recorded.

Endothelial cell migration and tube formation assay. For the assay of in vitro angiogenesis, tube formation of HUVECs in Matrigel Invasion Chambers was analyzed employing a coculture method. LoVo, LoVo/neo and LoVo/sTßRII cells that were preincubated for $48 \mathrm{~h}$ in MEM in the absence of $5 \mathrm{ng}$ $\mathrm{ml}^{-1}$ TGF- $\beta 1$ were plated in the outer chamber of Matrigel invasion chambers at a density of $0.5 \times 10^{5}$ cells $/ 500 \mu \mathrm{l}$ in
MEM and HUVECs were suspended in serum-free RPMI and seeded in the inner chamber. The chambers were incubated at $37^{\circ} \mathrm{C}$ for $72 \mathrm{~h}$. Following the incubation period, non-migrated cells on the upper surface of the filter were removed, and the cells that had migrated onto the filter were counted manually by examination under the microscope. Tube-like structures that formed in the gel were measured by total length per field (x250). Values were expressed as means and standard deviations of five fields.

Co-culture of peripheral blood mononuclear cells with LoVo cells and flow cytometry analysis. The peripheral blood mononuclear cells (PBMC) were isolated from peripheral blood obtained from adult volunteer donors using centrifugation through Lymphocyte Separation media. After adjustment of the cell concentration, Co-culture of peripheral blood mononuclear cells with LoVo, LoVo/neo and LoVo/sTßRII cells, respectively, were incubated for $48 \mathrm{~h}$ at $37^{\circ} \mathrm{C}$ and $5 \% \mathrm{CO}_{2}$. The cells were analyzed by the two-color flow cytometry method with a combination of monoclonal antibodies directly conjugated to fluorescein isothiocyanate (FITC) or phycoerythrin (PE). The following mixtures of antibodies were used: anti-CD4-FITC and anti-CD8-FITC. 
$\mathbf{A}$

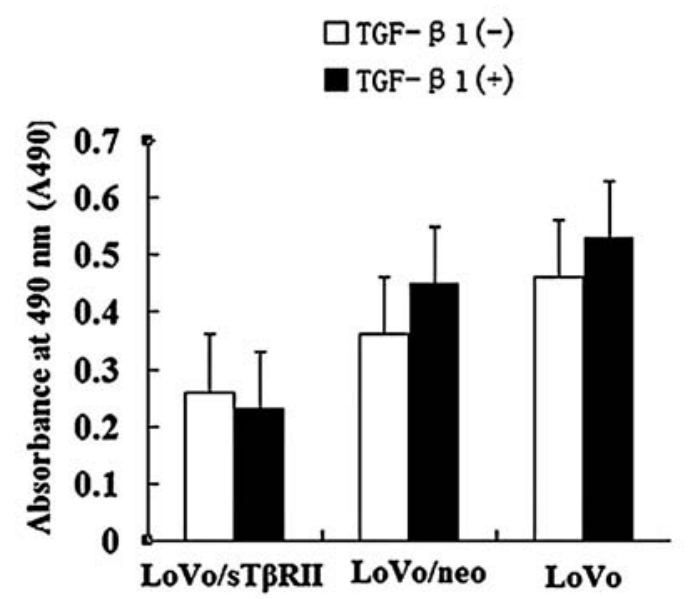

B

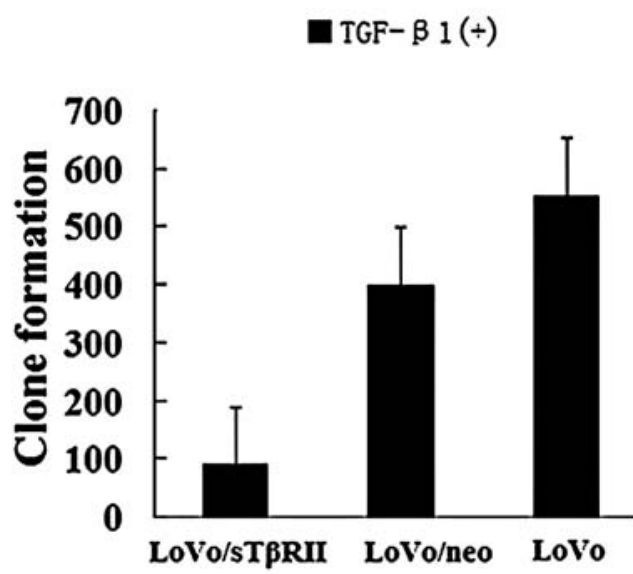

Figure 2. LoVo cells transfected with empty vector pcDNA3.1 (+) and pcDNA3.1 (+)/sTßRII were assayed for their resistance to the growth-promoting effects in the absence or presence of TGF-ß1 $\left(5 \mathrm{ng} \mathrm{ml}^{-1}\right)$. Results are the mean \pm SD of three independent determinations. (A) Relative cell number in each well was determined by an MTT assay as described in the Materials and methods and expressed as absorbance. (B) Number of clone formation.

Data analysis. Data are expressed as mean \pm standard deviation of the means. Data were considered statistically significant at $\mathrm{p}$-values $<0.05$ and data assessment was made using the statistics software program SPSS11.0.

\section{Results}

Identification of the expression of soluble TßRII in transfected LoVo cells. To determine if enhanced overexpression of the extracellular domain of TßRII (soluble TßRII) would interrupt TGF- $\$ 1$ signaling pathway in colon cancer cells and consequently suppress its effects on tumor growth and metastasis, we transfected eukaryotic expression plasmid encoding the entire domain (amino acids 1-159) of type II human TGF-3 [pcDNA3.1(+)/ sTßRII] into LoVo cells. As a control vector, pcDNA3.1 (+) vector with the neomycin resistance gene only [pcDNA3.1 (+)/neo] was also constructed. Transfected clones were selected after 3-4 weeks of growth in medium supplemented with G418, and these clones were selected because they displayed high levels of soluble TßRII mRNA expression by RT-PCR analysis (Fig. 1A). Expression of the soluble TßRII was also confirmed by Western blot analysis and immunofluorescence analysis (Fig. 1B and C). Western blot analysis indicated that LoVo/sTßRII cells secreted $15 \mathrm{ng} / \mathrm{ml}$ of soluble TßRII of $25-35 \mathrm{kDa}$ in size into the culture supernatant.

sTßRII inhibited colon cancer cell LoVo growth. Previous studies have shown that TGF- $\beta$ can stimulate cancer cell growth. To determine whether TGF- $\beta 1$ had similar function in human colorectal cancer LoVo cells, we treated LoVo cells with $5 \mathrm{ng} \mathrm{ml}^{-1}$ of TGF- $\beta$ for $48 \mathrm{~h}$. We found that the proliferation was significantly increased in the LoVo cells with TGF- $\beta$ treatment $(0.53 \pm 0.06)$, compared to the cells without treatment $(0.46 \pm 0.04, \mathrm{P}<0.05)$. However, the stimulation by TGF- $ß$ could be antagonized by sTßRII (Fig. 2), it was affected in the LoVo/neo and LoVo grew at similar rates in vitro (Fig. 2A). These data suggested that the

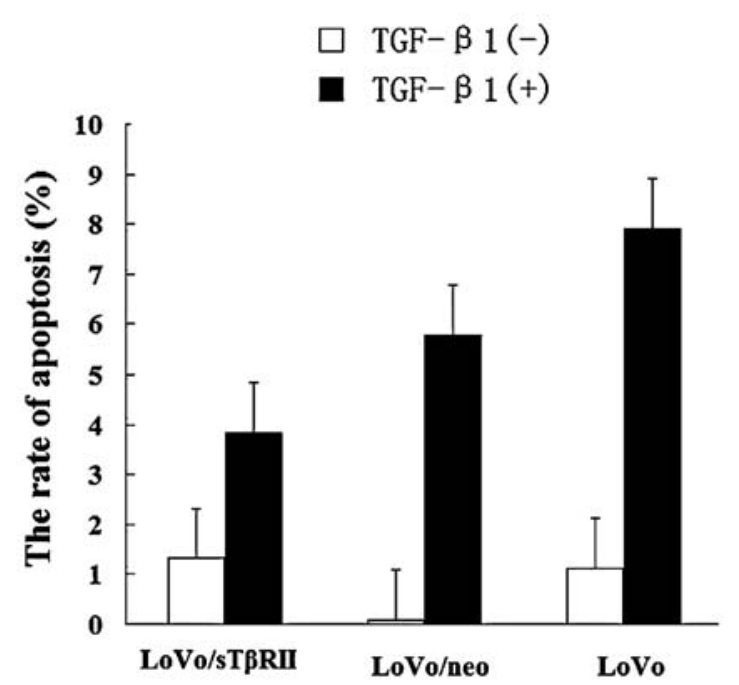

Figure 3. TGF-B1 induced apoptosis in LoVo cells analyzed by flow cytometry.

overexpresion of sTßRII inhibited cell growth and tumorigenicity in colon cancer cells through antagonizing the activity of TGF- 3 .

The expression of sTßRII attenuates TGFß1 inducedapoptosis. In this study, we found that TGF- 11 induced apoptosis in LoVo cells, but the induction of apoptosis by TGF-ß1 was attenuated by sTßRII (Fig. 3).

Invasion assay. To determine if sTßRII could inhibit TGF-ß1induced invasive capacity of colorectal cancer cells, we used sTBRII transfected cells and found that the overexpression of sTßRII significantly decreased the invasion of these cells in the presence of TGF- $31\left(5 \mathrm{ng} \mathrm{ml}^{-1}\right)$, in comparison with untransfected LoVo cells or mock transfected cells (LoVo/neo) (Fig. 4A and B). Thus, soluble TBRII was able to antagonize the biological actions of exogenous TGF- $\beta 1$. 
A

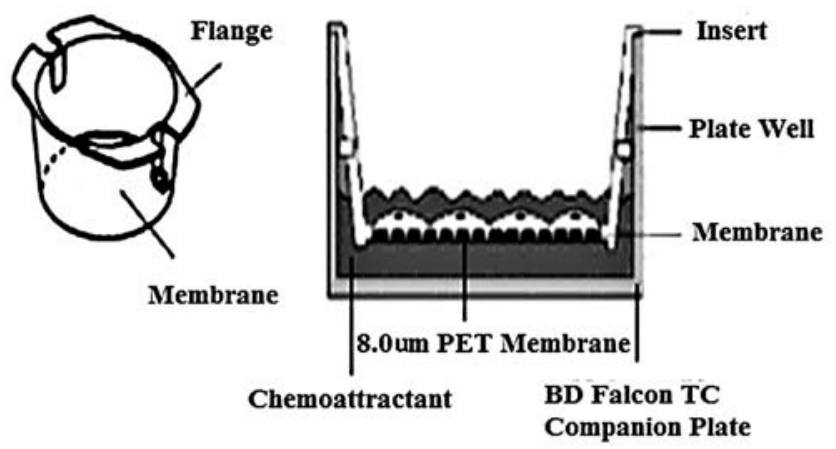

B

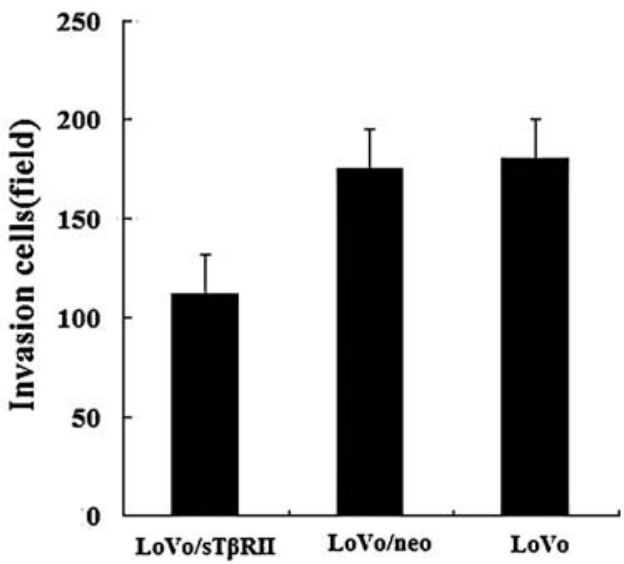

C

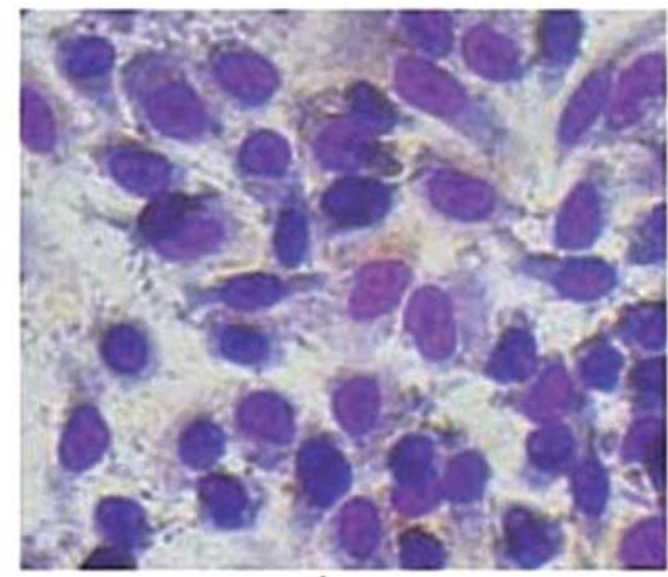

1

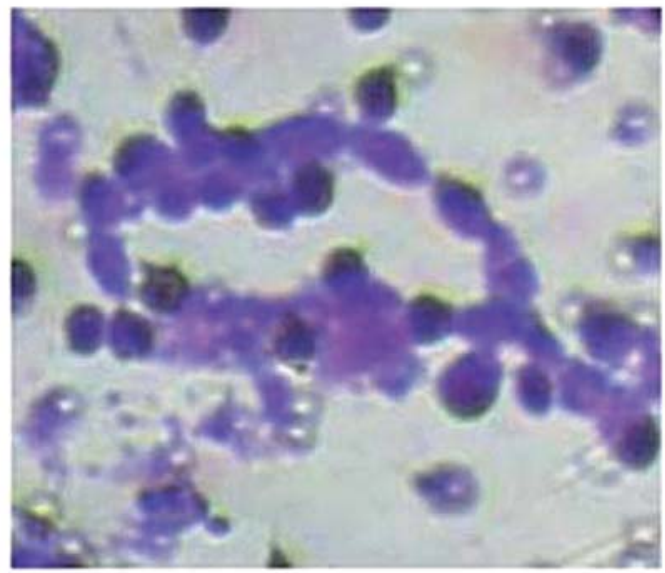

3
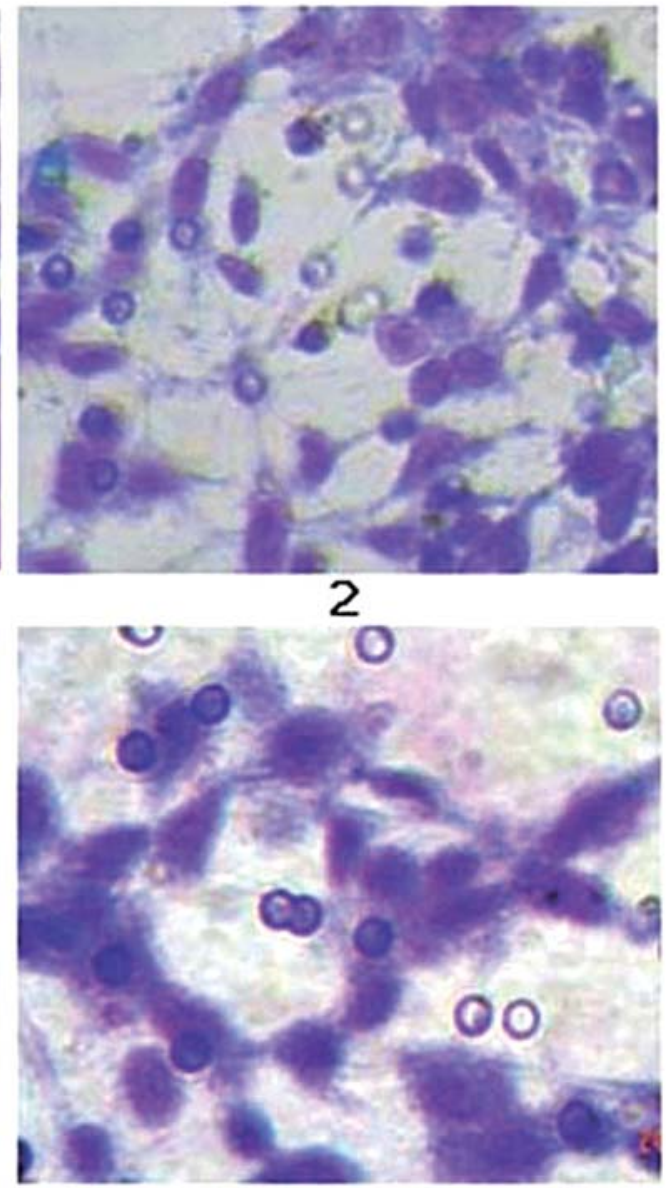

4

Figure 4. Effect of sTßRII expression on LoVo cell invasion and migration in co-cultured LoVo and HUVECs. (A) Schematic diagram of the migration assay chamber; (B) Invasion of LoVo cells in the presence of $5 \mathrm{ng} \mathrm{ml}^{-1}$ TGF-ß1. (C) Effect of sTßRII expression on angiogenesis in vitro, the number of tube-like structures that formed in the gel were measured by total length per field (x250). 1, The nomal phase of HUVECs. 2, HUVECs co-cultured with sTßRIIexpressing LoVo cells showed less tubular structure in the gel. 3, HUVECs co-cultured with LoVo/neo cells showed tubular structure in the gel. 4, HUVECs co-cultured with LoVo cells.

sTßRII inhibits the motility and angiogenesis in the cocultured colon cancer cells and endothelial cells. When cultured on Matrigel, endothelial cells rapidly align and form hollow tube-like structures. This in vitro model of angiogenesis is believed to resemble endothelial capillary web formation in vivo. To determine whether sTßRII could affect these properties of endothelial cells, we used the experimental set-up shown in Fig. 4A. In brief, a chemotaxis chamber was employed in which the lower chamber contained colorectal carcinoma cells LoVo, and the upper chamber contained 
A

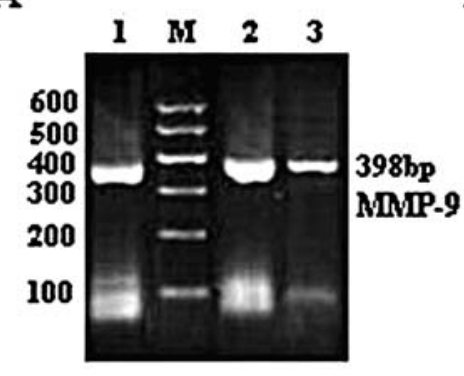

B

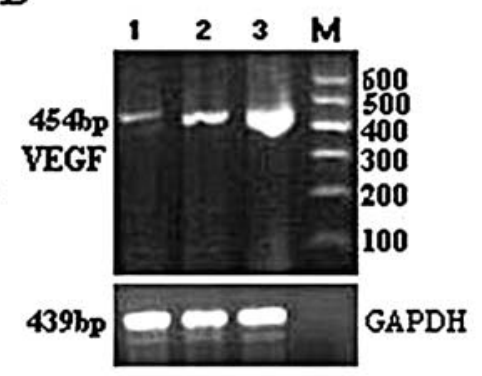

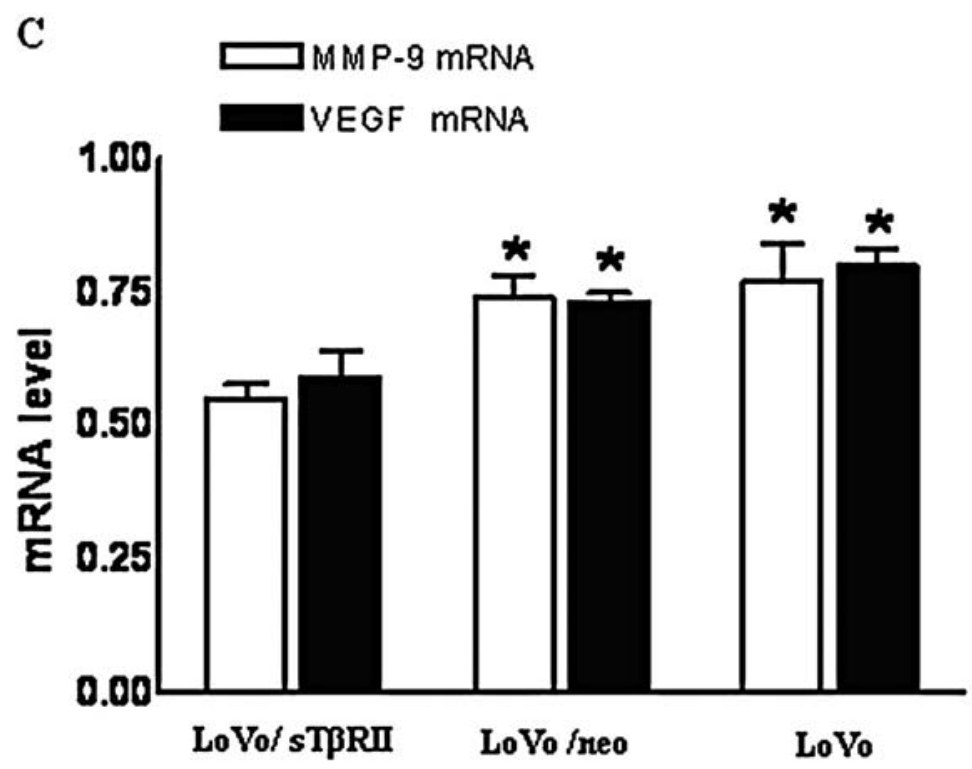

Figure 5. MMP-9 and VEGF mRNA expression. (A) M: Marker; 1, LoVo cells; 2, LoVo/neo cells; 3: MMP amplification product from LoVo/sTßRII cells by RT-PCR. (B) M: Marker; 1, VEGF amplification product from LoVo/ sTßRII cells by RT-PCR; 2, LoVo /neo cells; 3 , LoVo cells. (C) Semi-quantitative RT-PCR assay for VEGF and MMP-9 mRNA. ${ }^{*} \mathrm{P}<0.01$ when compared with the LoVo/sTßRII.

human umbilical vein endothelial cells (HUVECs). The number of endothelial cells that migrated through the gel to the bottom of the lower chamber was scored. As shown in Fig. 4C, the cells formed a network of capillary-like tubes. The mobilization or network cord formation of HUVECs in the response to sTßRII-overexpressing LoVo cells was reduced in the presence of $5 \mathrm{ng} \mathrm{ml}^{-1} \mathrm{TGF}-\beta 1$. In contrast, HUVECs co-cultured with mock LoVo cells showed high invasion or network cord formation in the presence of $5 \mathrm{ng}$ $\mathrm{ml}^{-1}$ TGF-ß31. sTßRII-overexpressing LoVo cells decreased the number of the endothelial tubular structures $(1.3 \pm 0.6)$ by 4- to 5-fold compared to that seen in mock LoVo cells (4.7 \pm 1.5$)$ and LoVo cells $(5.0 \pm 1.0)(\mathrm{F}=13.3, \mathrm{p}<0.01)$. Endothelial cells aligned themselves end to end and elongated to form a network (Fig. 4C). This finding indicated that sTßRII was capable of inhibiting the motility and angiogenesis.

sTßRII inhibits the MMP-9 and VEGF expression in the colon cancer cells. Previously reports have shown that TGF- 31 could directly stimulate angiogenesis by inducing expression of the angiogenesis-inducing factor vascular endothelial cell growth factor (VEGF) and induce capillary formation of endothelial cells cultured on a collagen matrix, and that TGFß1-induced expression of the metalloprotease MMP-9 and reduced tissue inhibitor of metalloproteases (TIMP) in tumor and endothelial cells, provide a protease-rich microenvironment that enhances cell migration and invasiveness of endothelial cells (17). Our data showed that LoVo cells secreted these angiogenic factors into the culture medium (Fig. 5). sTßRII overexpressing LoVo cells showed a decreased production of VEGF and MMP-9 compared to mock LoVo cells (Fig. 5), suggesting that sTßRII overexpressing LoVo cells inhibited the synthesis and secretion of MMP-9 and VEGF, further to inhibit endothelial cell motility through a matrix and inhibit angiogenesis.

sTßRII antagonizes the effect of immunity suppressed by $T G F-\beta$. The TGF- $\beta 1$ is one of the most potent immunosuppressive factors produced by many tumor cells. Since this cytokine exerts regulatory effects on various kinds of immune responses, such as maturation blockade of DCs, imbalance of Th function, inhibition of cytokine production responsible for priming $\mathrm{T}$ cells and impaired CTL activation (18). Thus, when tumors possess potent immunogenicity, neutralization of TGF- $\beta 1$ alone enhances antitumor immunity that has been induced in vivo in the presence of tumor, resulting in tumor regression. A previous report by Kobie et al (18) demonstrated that neutralization of TGF- $\beta 1$ by administration of anti-TGF- $\$ 1$ antibody enhanced the efficacy of a DC-based 


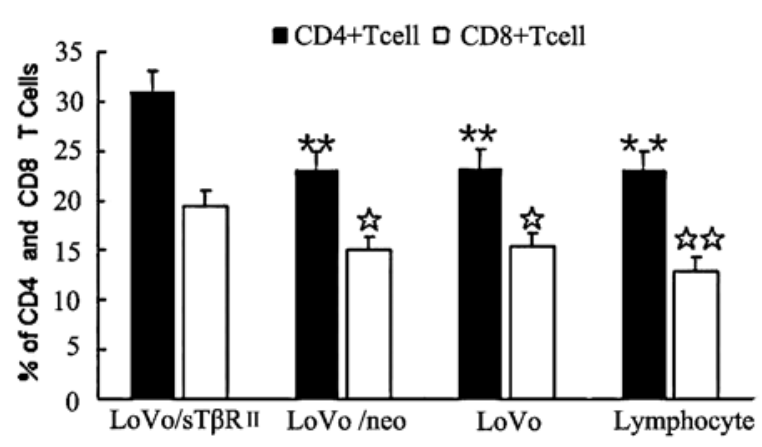

Figure 6. Co-culture of peripheral blood mononuclear cells with LoVo cells. ${ }^{* *} \mathrm{P}<0.01$ when compared with the LOVO/sTßPII.

vaccine. Our data showed that STßRII can antagonize the the immunosuppressive effect of TGF- 3 . sTßRII-overexpressing LoVo cells increased the percent of the CD4 and -8 compared to that seen in mock LoVo cells and LoVo cells $(\mathrm{p}<0.05)$ (Fig. 6).

\section{Discussion}

It was found that human tumors and tumor cell lines express higher levels of TGF- 31 mRNA compared to normal tissues (19). TGF- $B$ showed potent growth inhibition in some cancer cell lines. The tumor suppressive ability of TGF- $\beta$ has been demonstrated in model systems. It can induce cytostatic gene expression programs elucidated in studies with epithelial and lymphoid cells include activation of cyclin-dependent kinase inhibitors p15INK4B and p21WAF1 and repression growthenhancing transcription factors c-Myc and ID1-3 (20). Moreover, it promoted cell growth when tumor cells were resistant to TGF- $\beta$ mediated growth inhibition, and stimulated tumor progression, invasion and metastasis (21). Growing number of studies have shown that the increased TGF- $\beta$ production was also associated with poor pathological or clinical outcomes such as higher tumor grade, greater vascular counts, more metastases, and shorter survival time, which support that the excessive amount of TGF- $\beta$ may promote malignant progression (22).

High levels of TGF- $\beta$ in tumors have also been shown to correlate with angiogenesis (23). TGF- 31 stimulates VEGF via mitogen-activated protein kinase kinase 3 (MKK3) and activation of $\mathrm{p} 38 \alpha$ and $\mathrm{p} 38 \delta$ MAPK-dependent pathway in murine mesangial cells (24). The fact that TGF- $\beta$ has been shown to induce VEGF expression strongly suggests that TGF- $\beta$ may have a pro-angiogenic effect that would promote tumor progression. Thus, inhibiting TGF- $\beta$ signaling does not simply promote tumor growth but it has a profound effect on neoangiogenesis of the tumor that leads to tumor metastasis. A very important function of TGF- $\beta$ in the tumor stroma is the modulation of immune cells. TGF- $\beta$ is a potent immunosuppressive cytokine. Immunosuppressive properties of TGF- $\beta$ include inhibition of several dendritic cell (DC) functions, inhibition of T-cell differentiation into cytotoxic lymphocytes (CTLs) and Th cells, and inhibition of CD4 ${ }^{+} \mathrm{T}-$ cell differentiation into Th1 cells and Th2 cells (25). Thus, there is good evidence to suggest that TGF- $\beta$ is a potent factor that promotes metastasis in late stage tumors.

In colorectal cancer, the disruption of the TGF- $\beta$ signaling cascade is considered an important mechanism by which tumor cells can escape growth suppression (9). Attenuation of TGF- $\beta$ signaling correlates with tumor progression and enhanced metastatic potential in animal model and human patient samples. For instance, mutations of the TGF- $\beta$ receptor II and Smad are frequently observed in patients with colon cancer, suggesting a potential role for TGF- $\beta$ in preventing colon carcinogenesis $(9,26)$. Using a dominantnegative TGF-RII suppressed tumor progression in colon cancer (27). The TGF- $\beta$ pathway is targeted by loss-offunction mutations in various human cancers, thus relieving tumor cell growth from a major cytostatic agent and an inducer of apoptosis of diverse cell types (1). However, the precise role of TGF- $\beta$ signaling in colon carcinogenesis remains incompletely understood. Investigation of TGF- $\beta 1$ signal conduction pathway, have indicated that expression of soluble TßRII or soluble TßRII can alleviate tumorigenesis by neutralizing TGF- $\beta$ activity in tumor cells (28-30). Recently, utilizing a soluble TGF- $\beta$ receptor has attracted more attention. Rowland-Goldsmith et al showed that human pancreatic cancer COLO-357 cell clones expressing soluble TßRII were no longer showing growth even when stimulated by exogenous TGF- $\beta 1$, by transfecting a soluble TBRII encoding the extracellular domain into COLO-357, and that the cells exhibited a remarkable decrease in their invasive capacity in vitro. When injected s.c. into athymic mice, these clones exhibited attenuated growth rates and angiogenesis (28). Direct injection of Ad.s TßRFc into preestablished MDA-MB-231 breast tumors in nude mice causes significant inhibition of tumor growth and induces tumor regression (30).

In our previous study, we have demonstrated that TGF- $\beta 1$ played an important role in tumorigenesis and angiogenesis in colorectal cancer $(10,11)$. Consistent with previous studies, we found that LoVo cells were growing well with endogenous and exogenous TGF- $\beta 1$ exposure, but the promotion effect of TGF- 31 was attenuated in the pcDNA3.1(+)/sTßRIIexpressing LoVo cells (Fig. 2). Attenuation of TGF- 3 signaling by soluble TBRII also inhibited LoVo cell intravasation (Fig. 4). Our data also indicate that VEGF and MMP-9 expression were down-regulated by a blockade of exogenous TGF- $\beta 1$ signaling in LoVo cells, preventing angiogenesis (Fig. 5).TGF- $\beta$ is an active cytokine in the activation and inhibition of lymphocytes $(16,25)$. We observed that an elevated level of $\mathrm{CD}^{+}$and $8^{+}$regulatory $\mathrm{T}$ cells was accompanied by a higher proportion of soluble TßRII, TGF- $\beta$ is also recruited or activated by the immunosuppressive environment of the colorectal cancer cells inhibited by TBRII, where they may suppress the induction of antitumor immunity (Fig. 6).

In this study, we found that TGF- $\beta$ stimulates proliferation in colorectal cancer LoVo cells, which probably takes place through a Ras-dependent mechanism or the mutations of TßRII. In addition, TGF- $\beta$ can stimulate invasion and angiogenesis progression, possibly by its action on cellmatrix interaction or by stimulating VEGF and MMP activities. We found that a failure of the immune system to 
eradicate tumors is due to the immunosuppressive environment created by the growing tumor and TGF- $\beta$ was shown to be an immunosuppressive cytokine in cancer. Resistance to TGF- $\beta$-induced apoptosis may be an essential component of tumorigenesis (31), however in this study LoVo/sTßRII cells had no positive effect on TGF- $\beta$-induced apoptosis and some studies showed that TGF- $\beta 1$ also induced apoptosis in breast cancer, gastric cancer, hepatic cancer, lymphoma, ovarian cancer and prostate cancer cells $(31,32)$, suggesting that TGF- 31 plays two distinct roles in regulating cell maturation (including cell proliferation and apoptosis) in vitro.

We found that sTßRII can antagonize the signaling transduction of TGF- $\beta 1$ in tumorigenesis, but it also inhibited TGF-ß-induced apoptosis. Therefore, strategies to manipulate TGF- $\beta$ signaling for cancer therapy must consider its dual functions and develop strategies in combination and specific targeting in inhibiting tumor outgrowth and metastasis.

\section{Acknowledgements}

This study was supported in part by the grants from the National Natural Science Foundation of P.R. China (No. 30471981), the Scientific Research Foundation for the Returned Overseas Chinese Scholars, State Education Ministry (No. 20042176), the Natural Science Foundation of Hubei Province of P.R. China (No. 2003ABA179) and Key Technologies R\&D Program of Hubei Province (No. 2004AA304B06).

\section{References}

1. Levy L and Hill CS: Alterations in components of the TGF-beta superfamily signaling pathways in human cancer. Cytokine Growth Factor Rev 17: 41-58, 2006.

2. Pardali K and Moustakas A: Actions of TGF-beta as tumor suppressor and pro-metastatic factor in human cancer. Biochim Biophys Acta 1775: 21-62, 2007.

3. Coban S, Yüksel O, Koçkar MC, et al: The significance of serum transforming growth factor beta 1 in detecting of gastric and colon cancers. Hepatogastroenterology 54 : 1472-1476, 2007.

4. Angenete E, Langenskiöld M, Palmgren I, et al: Transforming growth factor beta- 1 in rectal tumour, mucosa and plasma in relation to radiotherapy and clinical outcome in rectal cancer patients. Int J Colorectal Dis 22: 1331-1338, 2007.

5. Bates RC, Pursell BM and Mercurio AM: Epithelial-mesenchymal transition and colorectal cancer: gaining insights into tumor progression using LIM 1863 cells. Cells Tissues Organs 185: 29-39, 2007.

6. Muraoka-Cook RS, Dumont N and Arteaga CL: Dual role of transforming growth factor $\beta$ in mammary tumorigenesis and metastatic progression. Clin Cancer Res 11: s937-s943, 2005.

7. Yan Z, Deng X and Friedman E: Oncogenic Ki-ras confers a more aggressive colon cancer phenotype through modification of transforming growth factor-beta receptor III. J Biol Chem 276: 1555-1563, 2001 .

8. Salovaara R, Roth S, Loukola A, et al: Frequent loss of SMAD4/ DPC4 protein in colorectal cancers. Mol Pathol 55: 385-388, 2002.

9. Biswas S, Chytil A, Washington K, et al: Transforming growth factor $\{$ beta $\}$ receptor type II inactivation promotes the establishment and progression of colon cancer. Cancer Res 64: 4687-4692, 2004.

10. Xiong B, Gong LL, Zhang F, et al: TGF-ß1 expression and angiogenesis in colorectal cancer tissue. World J Gastroenterology 8: 496-498, 2002.

11. Xiong B, Yuan HY, Hu MB, et al: Transforming growth factorbetal in invasion and metastasis in colorectal cancer. World $\mathrm{J}$ Gastroenterology 8: 674-678, 2002.
12. Peng SB, Yan L, Xia X, et al: Kinetic characterization of novel pyrazole TGF- 3 receptor I kinase inhibitors and their blockade of the epithelial-mesenchymal transition. Biochemistry 44: 2293-2304, 2005

13. Schlingensiepen KH, Schlingensiepen R, Steinbrecher A, et al: The TGF-ß32 antisense compound AP 12009. Cytokine Growth Factor Rev 17: 129-139, 2006.

14. Friese MA, Wischhusen J, Wick W, et al: RNA interference targeting transforming growth factor- $B$ enhances NKG2Dmediated antiglioma immune response, inhibits glioma cell migration and invasiveness, and abrogates tumorigenicity in vivo. Cancer Res 64: 7596-7603, 2004.

15. Yang YA, Dukhanina O, Tang B, et al: Lifetime exposure to a soluble TGF- $\beta$ antagonist protects mice against metastasis without adverse side effects. J Clin Invest 109: 1607-1615, 2002.

16. Suzuki E, Kapoor V, Cheung HK, et al: Soluble type II transforming growth factor-beta receptor inhibits established murine malignant mesothelioma tumor growth by augmenting host antitumor immunity. Clin Cancer Res 10: 5907-5918, 2004.

17. Rowland-Goldsmith MA, Maruyama H, Kusama T, et al: Soluble type II transforming growth factor (TGF-ß) receptor inhibits TGF- 3 signaling in COLO-357 pancreatic cancer cells in vitro and attenuates tumor formation. Clin Cancer Res 7: 2931-2940, 2001

18. Kobie JJ, Wu RS, Kurt RA, Lou S, Adelman MK, Whitesell LJ, Ramanathapuram LV, Arteaga CL and Akporiaye ET: Transforming growth factor $\beta$ inhibits the antigen-presenting functions and antitumor activity of dendritic cell vaccines. Cancer Res 63: 1860-1864, 2003.

19. Bian Y, Caldes T, Wijnen J, et al: TGFBR $1 * 6 \mathrm{~A}$ may contribute to hereditary colorectal cancer. J Clin Oncol 23: 3074-3078, 2005.

20. Bierie B and Moses HL: TGF- $B$ and cancer. Cytokine Growth Factor Rev 17: 29-40, 2006.

21. Elliott RL and Blobe GC: Role of transforming growth factor Beta in human cancer. J Clin Oncol 23: 2078-2093, 2005.

22. Kaklamani VG, Baddi L, Liu J, et al: Combined genetic assessment of transforming growth factor-\{beta\} signaling pathway variants may predict breast cancer risk. Cancer Res 65: 3454-3461, 2005.

23. Lu SL, Reh D, Li AG, et al: Overexpression of transforming growth factor $\beta 1$ in head and neck epithelia results in inflammation, angiogenesis, and epithelial hyper-proliferation. Cancer Res 64: 4405-4410, 2004.

24. Wang L, Kwak JH, Kim SI, et al: Transforming growth factor- $\beta 1$ stimulates vascular endothelial growth factor 164 via mitogen-activated protein kinase kinase 3-p38 $\alpha$ and p38 mitogen-activated protein kinase-dependent pathway in murine mesangial cells. J Biol Chem 279: 33213-33219, 2004.

25. Li MO, Wan YY, Sanjabi S, et al: Transforming growth factor-ß regulation of immune responses. Annu Rev Immunol 24: 99-146, 2006.

26. Fazhi Li, Cao Y, Courtney M, et al: TGF- $\beta$ signaling in colon cancer cells. World J Surg 29: 306-311, 2005.

27. Becker C, Fantini MC and Schramm C: TGF-beta suppresses tumor progression in colon cancer by inhibition of IL-6 transsignaling. Immunity 21: 491-501, 2004.

28. Rowland-Goldsmith MA, Maruyama H, Matsuda K, et al: Soluble typeII transforming growth factor- $\beta$ receptor attenuates expression of metastasis-associated genes and suppresses pancreatic cancer cell metastasis. Mol Cancer Ther 1: 161-167, 2002.

29. Suzuki E, Kapoor V, Cheung HK, et al: Soluble type II transforming growth factor-beta receptor inhibits established murine malignant mesothelioma tumor growth by augmenting host antitumor immunity. Clin Cancer Res 10: 5907-18, 2004.

30. Seth P, Wang ZG, Pister A, et al: Development of oncolytic adenovirus armed with a fusion of soluble transforming growth factor-beta receptor II and human immunoglobulin Fc for breast cancer therapy. Hum Gene Ther 17: 1152-1160, 2006.

31. Siegel PM and Massague J: Cytostatic and apoptotic actions of TGF-beta in homeostasis and cancer. Nat Rev Cancer 3: 807-821, 2003.

32. Ehata S, Hanyu A, Hayashi M, et al: Transforming growth factor-beta promotes survival of mammary carcinoma cells through induction of antiapoptotic transcription factor DEC1. Cancer Res 67: 9694-9703, 2007. 